\title{
Treatment of mixed type femoroacetabular impingement using safe surgical hip dislocation in adults
}

\author{
Erişkinlerde karışık tipteki femoroasetabüler sıkışmanın güvenli cerrahi \\ kalça dislokasyonu kullanılarak tedavisi
}

\author{
Ulukan İnan, MD., ${ }^{1}$ Selim Harmanşa, MD., ${ }^{2}$ Hakan Ömeroğlu, MD. ${ }^{1}$ \\ ${ }^{1}$ Department of Orthopedics and Traumatology, Eskişehir Osmangazi University Faculty of Medicine, Eskişehir, Turkey \\ ${ }^{2}$ Department of Orthopedics and Traumatology, Yunus Emre State Hospital, Eskişehir, Turkey
}

\begin{abstract}
Objectives: This study aims to assess the experience gained in a single institution in the treatment of mixed type femoroacetabular impingement (FAI) using safe surgical hip dislocation (SSHD) technique.
\end{abstract}

Patients and methods: In this study, 22 hips of 21 patients ( 7 males, 14 females; mean age 33.8 \pm 10.6 years; range 19-52 years) treated by SSHD technique in our clinic between October 2009 and October 2014 were retrospectively evaluated. Preoperative and final Harris hip scores (HHS) and alpha angles were compared. Age, gender, laterality, impingement tests, preoperative HHS, cam and pincer type FAI radiographic indicators and intraoperative articular findings were assessed in terms of their influence to the final functional outcomes.

Results: Mean duration of the symptoms was 29.5 months. Groin pain, activated by flexion and internal rotation of the hip, was the main symptom. A radiographic diagnosis of "mixed type FAI" was made in all hips. Mean follow-up duration of 22 hips was 48 months. The difference between the mean preoperative and latest HHS was statistically significant $(60.0$ vs. 87.6 points, $\mathrm{p}<0.001)$. The treatment was considered satisfactory in 17 of 22 hips (77\%) having a mean HHS of 95.0 points. Hips having a preoperative HHS of less than 60 points were more prone to unsatisfactory outcome. Among the investigated patient-dependent, clinical, radiographic variables and intraoperative articular findings, coxa profunda sign in a plain radiograph was found correlated with a higher rate of unsatisfactory outcome $(\mathrm{p}=0.040)$.

Conclusion: Safe surgical hip dislocation procedure has a success rate of $77 \%$ after a mean follow-up of four years. Coxa profunda sign is associated with the unsatisfactory clinical outcome. Preoperative HHS of less than 60 points seems to be a negative predictive variable on the clinical outcome.

Keywords: Femoroacetabular impingement; functional outcome; surgical hip dislocation; treatment.
ÖZ

Amaç: Bu çalışmada tek bir merkezde güvenli cerrahi kalça dislokasyonu (GCKD) tekniği kullanılarak karışık tipteki femoroasetabüler sıkışma (FAS) tedavisinde edinilen deneyim değerlendirildi.

Hastalar ve yöntemler: Çalışmada Ekim 2009 - Ekim 2014 tarihleri arasında kliniğimizde GCKD tekniği ile tedavi edilen 21 hastanın (7 erkek, 14 kadın; ort. yaş 33.8 \pm 10.6 yıl; dağılım 19-52 yıl) 22 kalçası geriye dönük olarak değerlendirildi. Ameliyat öncesi ve son Harris kalça skorları (HKS) ve alfa açıları karşılaştırıldı. Yaş, cinsiyet, taraf, sıkışma testleri, ameliyat öncesi HKS, tümsek ve kıskaç tip FAS radyografik göstergeleri ve ameliyat sırasındaki eklem bulguları en son işlevsel sonuçlar üzerindeki etkileri yönünden değerlendirildi.

Bulgular: Semptomların ortalama süresi 29.5 aydı. Kalçanın fleksiyonu ve iç rotasyonu ile ortaya çıkan kasık ağrısı başlıca semptomdu. Tüm kalçalara radyografik olarak "karışık tipte FAS" tanısı konuldu. Yirmi iki kalçanın ortalama izlem süresi 48 aydı. Ameliyat öncesi ve en son ortalama HKS arasındaki farklılık istatistiksel olarak anlamlıydı (60.0’a karşın 87.6 puan, $\mathrm{p}<0.001)$. Yirmi iki kalçadan ortalama HKS'si 95.0 puan olan 17 kalçada (\%77) tedavi yeterli olarak değerlendirildi. Ameliyat öncesi HKS'si 60 puanın altında olan kalçalar yetersiz sonuca biraz daha fazla yatkındı. Araştırılan hasta bağımlı, klinik, radyografik değişkenler ve ameliyat sırasındaki eklem bulguları içinde düz bir grafideki koksa profunda belirtisi daha yüksek bir yetersiz sonuç oranı ile ilişkili bulundu $(\mathrm{p}=0.040)$.

Sonuç: Güvenli cerrahi kalça dislokasyonu işlemi ortalama dört yıllık izlem sonrasında \%77’lik bir başarı oranına sahiptir. Koksa profunda belirtisi yetersiz klinik sonuç ile bağlantılıdır. Ameliyat öncesi 60 puanın altındaki bir HKS klinik sonuç üzerinde negatif belirleyici bir değişken olarak görünmektedir.

Anahtar sözcükler: Femoroasetabüler sıkışma; işlevsel sonuç; cerrahi kalça dislokasyonu; tedavi.

- Received: March 10,2016 Accepted: June 07, 2016

- Correspondence: Ulukan İnan, MD. Eskişehir Osmangazi Üniversitesi Tıp Fakültesi Ortopedi ve Travmatoloji Anabilim Dalı, 26040 Eskișehir, Turkey. Tel: +90 222 - 2392979 Fax: +90 222 - 2397691 e-mail: ulukaninan@gmail.com 
Femoroacetabular impingement (FAI) defines the alterations in the anatomy of acetabulum and/or femur head/neck junction, which may lead to restrictions in daily life and cause clinical symptoms in particular hip movements. If the femur head/neck junction loses its curve and becomes aspherical, then it is called a cam type FAI. If there is an excessive acetabular cover of the femoral head, then it is called a pincer type FAI. If both the cam and pincer types are present, then it is called a mixed type FAI. ${ }^{[1,2]}$ The defined alterations in the acetabular and/or proximal femoral bone morphology may cause early deterioration in the structure of the acetabular hyaline cartilage, so FAI has been considered as one of the most important causes of hip osteoarthritis (HOA). ${ }^{[1,2]}$

Surgical treatment of FAI using safe surgical hip dislocation (SSHD) was initially reported by the Bernese group led by Ganz in early 2000s. ${ }^{[3]}$ Safe surgical hip dislocation allows a clear visualization of the intraarticular pathologic alterations and an effective elimination of the bony and soft tissue distortions, causing clinical symptoms. This method of treatment has gained a worldwide popularity since then.

Several articles assessing the outcomes of SSHD in adults with FAI have already been published in the international literature. Safe surgical hip dislocation has gained a nationwide popularity for the last 7-8 years in Turkey and the number of published international articles about SSHD from the national institutions is increasing. ${ }^{[4,5]}$

We hypothesized that several factors might influence the functional outcome in FAI treated by using SSHD. Therefore, in this study, we aimed to assess the experience gained in a single institution in the treatment of mixed type FAI using SSHD technique.

\section{PATIENTS AND METHODS}

This retrospective case series included 22 hips of 21 patients ( 7 males, 14 females; mean age 33.8 \pm 10.6 ; years; range 19 to 52 years) who had diagnosis of mixed type FAI, were operated on using the SSHD technique at Medical Faculty of Eskişehir Osmangazi University, Department of Orthopedics and Traumatology, between October 2009 and October 2014, and had minimum one-year of complete clinical and radiographic follow-up. The study protocol was approved by the Medical Faculty of Eskişehir Osmangazi University Ethics Committee. A written informed consent was obtained from each patient.
The study was conducted in accordance with the principles of the Declaration of Helsinki.

The complaints of all patients were initially recorded in detail. Anterior and posterior impingement tests ${ }^{[6]}$ and Harris hip score (HHS) ${ }^{[7]}$ were used for the clinical assessment of the patients.

In the radiographic examination, anteroposterior pelvic view, false-profile view, frog-leg lateral view, and $90^{\circ}$ Dunn view were taken in the supine position in all patients. ${ }^{[8,9]}$ An alpha angle of more than $50^{\circ}$, pistol-grip sign and coxa vara (femur neck-shaft angle $<120^{\circ}$ ) were considered as "the radiographic

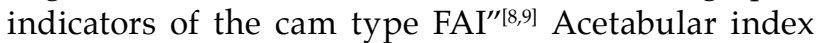
angle of Tönnis less than $1^{\circ}$, center-edge angle of Wiberg more than $39^{\circ}$, cross-over sign, coxa profunda or acetabular protrusion, ischial spine sign, posterior wall sign, narrowing of the posteroinferior joint space and os acetabuli were considered as "the radiographic indicators of the pincer type $\mathrm{FAI}^{\prime \prime}{ }^{[8,9]}$ Preoperative multidetector computed tomography arthrography and magnetic resonance arthrography were performed to assess the labral tear and acetabular cartilage delamination and to establish a better management planning in all patients. ${ }^{[10]}$ The management plan was offered to the patients after assessing all clinical and radiological findings and determining the type of the FAI.

The SSHD technique described by Ganz et al. ${ }^{[3]}$ was performed by the same surgical team in all patients. A curved surgical incision was used in 18 hips and a straight incision was used in the last four hips. A straight trochanteric osteotomy was performed in all hips. In one hip, cup hemiarthroplasty was performed due to severe cartilaginous damage on the femoral head. A major intraoperative bleeding was not seen in any of the patients. Parenteral antibiotic prophylaxis for 48 hours and parenteral thromboembolism prophylaxis for 10 days were applied in all patients. Passive hip movements were started and patients were allowed to walk with crutches within 24-48 hours following surgery. The patients were allowed for full weight bearing with one or two crutches at postoperative six weeks.

We initially aimed to compare preoperative and the latest HHS and alpha angles as well as to assess the effect of patient dependent-variables such as age, gender, laterality, impingement tests, radiographic (cam and pincer type FAI indicators) parameters and intraoperative articular findings on the functional outcome of the surgical treatment. The final result was considered "satisfactory", if a hip had minimum HHS of 80 points at the latest follow-up ${ }^{[7]}$ and did 
not undergo total hip arthroplasty (THA) due to progressive radiological degenerative changes as well as persisting symptoms during follow-up. The latest clinical and radiographic records prior to the THA surgery were used in hips in which a further THA operation would be performed.

\section{Statistical analysis}

For the statistical analysis of the data, the paired $t$ test was used to compare the means of paired samples, Mann-Whitney $U$ test was used to compare the means of two independent samples and the chisquare test was used to compare the frequencies of two groups. A $p$ value less than 0.05 was considered significant.

\section{RESULTS}

The affected side was right hip in eight patients, left hip in 12 patients, and both hips in one female patient.

The mean duration of symptoms from beginning to the diagnosis of FAI was 29.5 \pm 23.4 (range 8-84) months. The groin pain during flexion and internal rotation of the hip joint was the main symptom in all patients. In the clinical examination, anterior and posterior impingement tests were positive in $22(100 \%)$ and $18(82 \%)$ hips, respectively. The mean preoperative HHS of 22 hips was 60.0 \pm 8.4 (range 49-79) points.

According to the radiographic findings, "mixed type FAI" was present in all hips. Radiographic indicators of moderate or severe type of HOA were not present in any of the hips, preoperatively (Figure 1).

Pistol grip sign was present in all hips and coxa vara in four hips having cam type FAI findings. The mean preoperative alpha angle was $65.1^{\circ} \pm 5.0^{\circ}$ (range $59^{\circ}-76^{\circ}$ ).

Cross-over sign was seen in 18 hips, coxa profunda in 12 hips, acetabular protrusion in one hip, ischial spine sign in nine hips, posterior wall sign in five hips, narrowing of the posteroinferior joint space in 16 hips, and os acetabuli in 10 hips having pincer type FAI findings. The mean preoperative acetabular index angle of Tönnis and center-edge angle of Wiberg were $-0.7^{\circ} \pm 2.5^{\circ}$ (ranges from $-8^{\circ}$ to $+3^{\circ}$ ) and $41.2^{\circ} \pm 8.4^{\circ}$ $\left(27^{\circ}-56^{\circ}\right)$, respectively.

A prominent local labral tear commonly located at the anterosuperior acetabular area was present in 11 hips and an extensive detachment and severe degeneration of the labrum in two hips. Repair of the torn labrum was performed in 10 hips and excision of the severely degenerated and detached labrum in two hips. Delamination of the acetabular cartilage in the weight-bearing zone was observed in
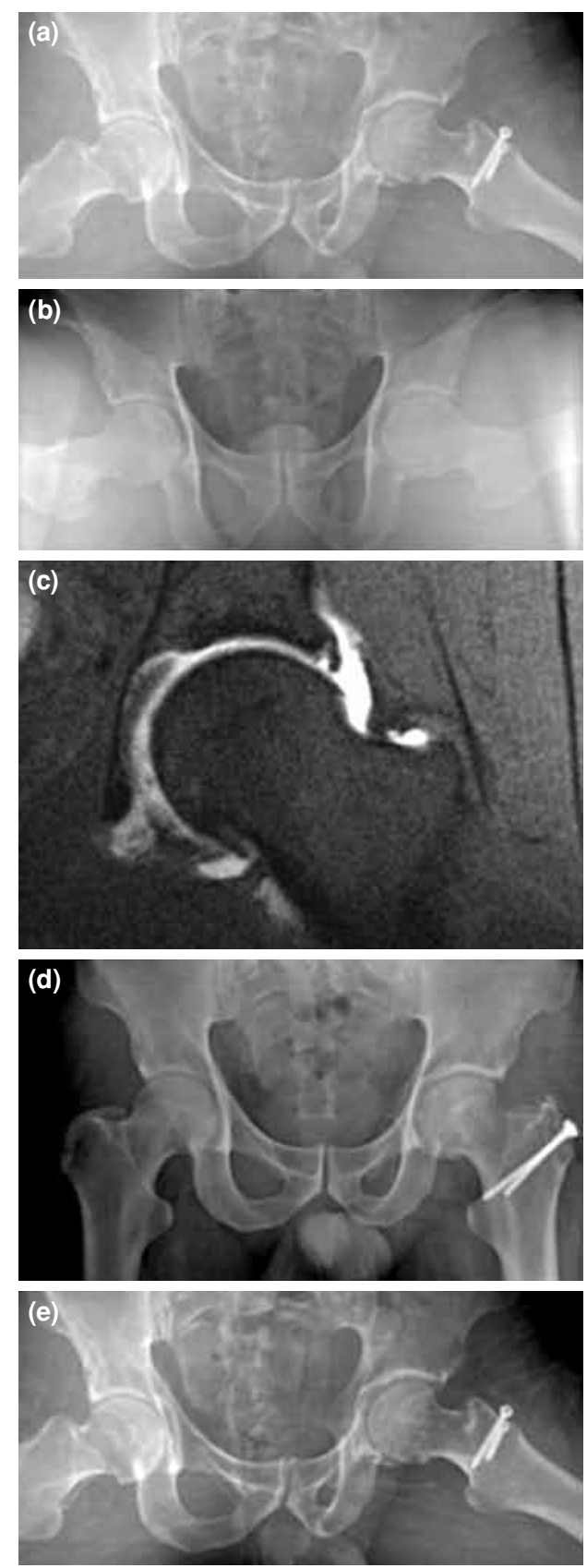

Figure 1. Preoperative anteroposterior (a), frog-leg (b) pelvis radiographs and arthromagnetic resonance imaging (c) of a 36-year-old male patient, who had persisting symptoms in his left hip for 12 months due to mixed type femoroacetabular impingement. A labral tear is seen in his preoperative arthromagnetic resonance imaging. Postoperative anteroposterior (d) and frog-leg pelvis radiographs (e) of same patient following safe surgical hip dislocation in which labral excision, microfracture of the acetabular chondral lesions, acetabular anterosuperior wall trimming, and femoral neck osteoplasty have been performed. Patient is highly satisfied with his functional improvement at postoperative five years. 
16 hips and cartilage debridement accompanied with micro fracture was performed in all these hips. The dimension of all cartilaginous lesions was less than $1 \mathrm{~cm}^{2}$. Acetabular wall trimming was performed in 14 hips. Osteoplasty of the femur head/neck junction was performed in all hips.

The mean follow-up duration of 22 hips was $48.0 \pm 20.0$ (range 12-71) months. The latest mean HHS of 22 hips was $87.6 \pm 15.6$ (range 49-100) points. The difference between the preoperative and the latest mean HHS of 22 hips was considered statistically significant $(\mathrm{p}<0.001)$. The final outcome was considered "satisfactory" in 17 of 22 hips (77\%) having a mean HHS of 95 points after a mean followup of four years (Table I). Among five hips with an unsatisfactory outcome, four already underwent total hip arthroplasty surgery due to persisting symptoms and progressive HOA within the first three years following the primary surgery. A second-look hip arthroscopy was performed in one hip with an unsatisfactory clinical outcome, but no significant arthroscopic findings or significant radiological alterations including avascular necrosis of the femoral head were found. Minor trochanteric irritation on the trochanteric osteotomy site, which had no adverse effects on the clinical outcome, was observed in eight hips $(36 \%)$. Neuropraxia of the sciatic nerve was not observed.

Latest mean alpha angle of 21 hips (the one in which cup arthroplasty had been performed was not included) was $51.2^{\circ} \pm 3.2^{\circ}$ (range $44^{\circ}-57^{\circ}$ ). The correction in the alpha angle, when compared with the preoperative mean alpha angle, was considered statistically significant $(\mathrm{p}<0.001)$.

Radiographic findings of avascular necrosis were not seen in any of the hips during follow-up. Heterotopic ossification was seen in two hips (9\%). Breakage of one of the two $4.5 \mathrm{~mm}$ cortical screws, used for the fixation of the trochanteric osteotomy, was seen in one hip at postoperative three months, but did not affect the bone union process at the osteotomy site.

Latest mean HHS was significantly higher in hips with "satisfactory outcome" than in ones with "unsatisfactory outcome" $(\mathrm{p}<0.001)$ (Table I). Mean preoperative HHS was somewhat higher in hips with "satisfactory outcome" than in ones with "unsatisfactory outcome" $(\mathrm{p}=0.059)$. It was seen that none of the preoperative HHS of the hips with unsatisfactory outcome exceeded 58 points (Table I). Coxa profunda sign was the only variable that was correlated with a higher rate of "unsatisfactory outcome" ( $p=0.040)$ (Table I). Rate of os acetabuli was higher in hips with satisfactory outcome.

\section{DISCUSSION}

The problem of missed or delayed diagnosis still exists in patients having FAI and this has a significant effect on the natural history of the problem and increases the risk of development of HOA. ${ }^{[2,6]}$ The mean duration between the initiation of the symptoms and making the diagnosis was about 2.5 years in the present study and this might have adverse effects on the outcomes of the patients. Groin pain, provoked by certain hip movements, was the main symptom of the patients in the present study and this finding correlated well with findings in the literature. ${ }^{[2,6]}$ Our experiences have shown us that the physicians dealing with pain and irritability symptoms especially around the groin and anterior/lateral thigh regions should be informed well concerning the clinical presentation of FAI in order to avoid missed or delayed diagnosis in FAI.

In a meta-analysis, the anterior impingement test was considered as the most valuable screening test in FAI. ${ }^{[11]}$ The sensitivity of anterior impingement test for FAI was found to be $100 \%$ in the present study. In our daily practice, anterior and posterior impingement tests are two of the several routine hip examination tests in adolescents and adults.

Radiographic indicators of cam and pincer type FAI were previously well defined. ${ }^{[8,9]}$ Among the cam type indicators, the sensitivity of pistol-grip sign was $100 \%$ in the present study. The hips had a higher preoperative mean of alpha angle. Among the pincer type indicators, crossover sign, narrowing of the posteroinferior joint space, and coxa profunda were the three most commonly seen ones. Besides, the hips had higher preoperative means of acetabular index and center-edge angles. However, it should be remembered that the radiographic indicators of FAI could even be seen in a higher percentage of healthy young adults without any hip complaints. ${ }^{[12]}$ So, these radiographic indicators become valuable when the patients have symptoms and clinical findings.

Although there has been a trend towards the arthroscopic treatment of FAI, according to the findings of three systematic reviews, both arthroscopic and open surgical techniques have similar and higher rates of satisfactory clinical outcomes at short/mid-term follow-up and there still exists no high level of scientific evidence concerning the superiority of one surgical technique to another. ${ }^{[13-15]}$ According to the results of the published studies in which the number of hips has 
TABLE I

Correlation between several patient-dependent, clinical, radiographic, and intraoperative articular variables with final outcome

\begin{tabular}{|c|c|c|c|c|c|c|c|c|c|}
\hline & \multicolumn{4}{|c|}{ Satisfactory outcome $(n=17)$} & \multicolumn{4}{|c|}{ Unsatisfactory outcome $(n=5)$} & \multirow[b]{2}{*}{$p$} \\
\hline & $\mathrm{n}$ & $\%$ & Mean $\pm S D$ & Min.-Max. & $\mathrm{n}$ & $\%$ & Mean $\pm S D$ & Min.-Max. & \\
\hline Age (years) & & & $34.9 \pm 9.5$ & $19-50$ & & & $30.0 \pm 14.3$ & $19-52$ & 0.367 \\
\hline $\begin{array}{l}\text { Gender } \\
\text { Females } \\
\text { Males }\end{array}$ & $\begin{array}{c}11 \\
6\end{array}$ & $\begin{array}{l}73 \\
86\end{array}$ & & & $\begin{array}{l}4 \\
1\end{array}$ & $\begin{array}{l}27 \\
14\end{array}$ & & & 1.0 \\
\hline $\begin{array}{l}\text { Laterality } \\
\text { Right } \\
\text { Left }\end{array}$ & $\begin{array}{c}7 \\
10\end{array}$ & $\begin{array}{l}78 \\
77\end{array}$ & & & $\begin{array}{l}2 \\
3\end{array}$ & $\begin{array}{l}22 \\
23\end{array}$ & & & 1.0 \\
\hline Duration of symptoms (months) & & & $29.6 \pm 23.4$ & $8-84$ & & & $29.4 \pm 26.0$ & $9-72$ & 0.937 \\
\hline $\begin{array}{l}\text { Anterior impingement test } \\
\text { Yes } \\
\text { No }\end{array}$ & $\begin{array}{c}17 \\
0\end{array}$ & & & & $\begin{array}{l}5 \\
0\end{array}$ & & & & $N / A$ \\
\hline $\begin{array}{l}\text { Posterior impingement test } \\
\text { Yes } \\
\text { No }\end{array}$ & $\begin{array}{c}13 \\
4\end{array}$ & $\begin{array}{c}72 \\
100\end{array}$ & & & $\begin{array}{l}5 \\
0\end{array}$ & $\begin{array}{c}28 \\
-\end{array}$ & & & 0.535 \\
\hline Preoperative HHS & & & $61.8 \pm 8.7$ & $50-79$ & & & $54.2 \pm 3.6$ & $49-58$ & 0.059 \\
\hline Latest HHS & & & $95.0 \pm 5.2$ & $80-100$ & & & $62.2 \pm 11.0$ & $49-76$ & $<0.001^{*}$ \\
\hline $\begin{array}{l}\text { Pistol-grip sign } \\
\text { Yes } \\
\text { No }\end{array}$ & $\begin{array}{c}17 \\
0\end{array}$ & & & & $\begin{array}{l}5 \\
0\end{array}$ & & & & $\mathrm{~N} / \mathrm{A}$ \\
\hline $\begin{array}{l}\text { Coxa vara } \\
\text { Yes } \\
\text { No }\end{array}$ & $\begin{array}{c}3 \\
14\end{array}$ & $\begin{array}{l}75 \\
78\end{array}$ & & & $\begin{array}{l}1 \\
4\end{array}$ & $\begin{array}{l}25 \\
22\end{array}$ & & & 1.0 \\
\hline Preoperative alpha angle $\left(^{\circ}\right)$ & & & $65.2 \pm 3.9$ & $59-71$ & & & $64.8 \pm 8.3$ & $54-76$ & 0.969 \\
\hline Latest alpha angle $\left({ }^{\circ}\right)$ & & & $51.2 \pm 3.4$ & $44-57$ & & & $51.4 \pm 3.0$ & $48-55$ & 0.967 \\
\hline Preoperative center-edge angle $\left({ }^{\circ}\right)$ & & & $41.7 \pm 8.9$ & $27-56$ & & & $39.6 \pm 7.1$ & $29-52$ & 0.479 \\
\hline Preoperative acetabular index angle $\left(^{\circ}\right)$ & & & $-1.1 \pm 2.7$ & -8 to 3 & & & $0.6 \pm 1.3$ & $0-3$ & 0.193 \\
\hline $\begin{array}{l}\text { Cross-over sign } \\
\text { Yes } \\
\text { No }\end{array}$ & $\begin{array}{c}15 \\
2\end{array}$ & $\begin{array}{l}83 \\
50\end{array}$ & & & $\begin{array}{l}3 \\
2\end{array}$ & $\begin{array}{l}17 \\
50\end{array}$ & & & 0.210 \\
\hline $\begin{array}{l}\text { Coxa profunda } \\
\text { Yes } \\
\text { No }\end{array}$ & $\begin{array}{c}7 \\
10\end{array}$ & $\begin{array}{c}58 \\
100\end{array}$ & & & $\begin{array}{l}5 \\
0\end{array}$ & $\begin{array}{c}42 \\
-\end{array}$ & & & $0.040^{*}$ \\
\hline $\begin{array}{l}\text { Ischial spine sign } \\
\text { Yes } \\
\text { No }\end{array}$ & $\begin{array}{c}7 \\
10\end{array}$ & $\begin{array}{l}78 \\
77\end{array}$ & & & $\begin{array}{l}2 \\
3\end{array}$ & $\begin{array}{l}22 \\
23\end{array}$ & & & 1.0 \\
\hline $\begin{array}{l}\text { Posterior wall sign } \\
\text { Yes } \\
\text { No }\end{array}$ & $\begin{array}{c}4 \\
13\end{array}$ & $\begin{array}{l}80 \\
76\end{array}$ & & & $\begin{array}{l}1 \\
4\end{array}$ & $\begin{array}{l}20 \\
24\end{array}$ & & & 1.0 \\
\hline $\begin{array}{l}\text { Posteroinferior joint narrowing } \\
\text { Yes } \\
\text { No }\end{array}$ & $\begin{array}{c}13 \\
4\end{array}$ & $\begin{array}{l}81 \\
67\end{array}$ & & & $\begin{array}{l}3 \\
2\end{array}$ & $\begin{array}{l}19 \\
33\end{array}$ & & & 0.419 \\
\hline $\begin{array}{l}\text { Os acetabuli } \\
\text { Yes } \\
\text { No }\end{array}$ & $\begin{array}{c}10 \\
7\end{array}$ & $\begin{array}{c}100 \\
58\end{array}$ & & & $\begin{array}{l}0 \\
5\end{array}$ & - & & & $0.040^{*}$ \\
\hline $\begin{array}{l}\text { Labral tear } \\
\text { Yes } \\
\text { No }\end{array}$ & $\begin{array}{l}9 \\
8\end{array}$ & $\begin{array}{l}69 \\
89\end{array}$ & & & $\begin{array}{l}4 \\
1\end{array}$ & $\begin{array}{l}31 \\
11\end{array}$ & & & 0.293 \\
\hline $\begin{array}{l}\text { Cartilage delamination } \\
\text { Yes } \\
\text { No }\end{array}$ & $\begin{array}{c}12 \\
5\end{array}$ & $\begin{array}{l}75 \\
83\end{array}$ & & & $\begin{array}{l}4 \\
1\end{array}$ & $\begin{array}{l}25 \\
17\end{array}$ & & & 1.0 \\
\hline
\end{tabular}

SD: Standard deviation; Min.: Minimum; Max.: Maximum; N/A: Not available; HHS: Harris hip score. ${ }^{*}$ Significant difference $(p<0.05)$. 
ranged from 19 to 60 and the mean follow-up has ranged from 2 years to 5.2 years, treatment of FAI by SSHD provides a significant improvement in the early functional outcome of the adult patients. ${ }^{[13]}$ The rate of excellent and good clinical results following SSHD in FAI has been about $80 \%$ in the published studies performed in adults. ${ }^{[14]}$ Arthroscopic group patients only have better improvement in general health related quality of life scores than SSHD group patients. ${ }^{[15]}$ In the present study, all hips had mixed type FAI with moderate to severe clinical, radiological, and intraoperative findings and an arthroscopic treatment could have been difficult to overcome all the bony and soft tissue alterations in most of the patients. The findings of the present study revealed a significant functional improvement in 17 out of 22 hips (77\%) after a mean follow-up of four years. Among the five hips with unsatisfactory outcome, none of them had a preoperative HHS of more than 60 points. Age, gender, and laterality had no significant effects on the clinical outcome. Among the assessed radiographic indicators of FAI, coxa profunda sign was the only one having adverse effects on the final clinical outcome, as none of the hips without coxa profunda sign in the preoperative plain radiographs would have an unsatisfactory clinical outcome. However, coxa profunda sign was found as a common radiographic finding even in healthy and asymptomatic subjects, so it was considered as a benign alteration in the hip morphology as well as a nonspecific radiographic indicator of pincer type FAI. ${ }^{[16,17]}$ The findings of our study including limited number of cases are not compatible with the ones of the previously mentioned studies. We believe that coxa profunda sign needs to be revisited in larger FAI case series including symptomatic and surgically treated patients. The results of the present study revealed that the rate of os acetabuli was higher in hips with satisfactory outcome than in hips with unsatisfactory outcome. However, we believe that this can be an accidental finding as os acetabuli is an anatomical obstacle to certain hip movements.

Open labral debridement and acetabular/femoral neck osteoplasty were reported as successful procedures for providing favorable postoperative hip scores. ${ }^{[14]}$ In the present study, labral repair/ excision was performed in 55\% of the hips, acetabular cartilage debridement and micro fracture in $73 \%$, acetabular wall trimming in $64 \%$, and femoral neck osteoplasty in all. A significant improvement in the alpha angle was obtained following femoral neck osteoplasty. There was no significant correlation between the intraoperative labral and cartilaginous alterations and the final outcome. We suggest that it is utmost important to establish and then to eliminate all the bony alterations causing impingement intraoperatively as well as to treat the labral and cartilaginous problems. Although all the hips had an initial diagnosis of mixed type FAI, we performed acetabular trimming in two third of the hips. This was because mixed type FAI was a radiographic diagnosis, but we made our final decision concerning the need of an acetabular trimming after performing intraoperative hip impingement tests.

It was initially reported that an anterior hip dislocation with minor and controlled surgical trauma did not impair the femoral head perfusion. ${ }^{[3]}$ None of the hips in the present study had radiological signs of femoral head avascular necrosis during follow-up.

The other reported complications of SSHD are trochanteric nonunion, trochanteric discomfort due to bursitis, and progression of HOA and subsequent conversion to THA. ${ }^{[13]}$ In the present study, rates of the postoperative occurrence of minor trochanteric discomfort and the need for subsequent THA due to progressive clinical discomfort and radiographic degenerative changes were $36 \%$ and $18 \%$, respectively. We believe that the need for a subsequent THA during follow-up may increase in hips with preoperative low HHS.

There are three shortcomings of the present study. First, the number of patients was not so high for drawing stronger conclusions. The unsatisfactory outcome group had only five patients and this could have a negative impact on the power of the statistical analysis. However, mid-term experience of a national institution with a technically demanding and widely used operative technique in complicated intraarticular hip pathologies can be considered a significant scientific contribution to the literature. Second, we only evaluated the clinical outcomes of the patients but did not evaluate the radiographic findings of HOA at the latest follow-up. Such an evaluation could have helped us to draw conclusions concerning the use of SSHD on preventing HOA in FAI. Third, we did not have a data comparing the results of SSHD with the other surgical techniques, as this would have helped to determine the usability of the presented technique more effectively.

With the numbers available in the study, we can conclude that SSHD provides a considerable functional improvement in $77 \%$ of the patients with mixed type FAI after a mean follow-up of four years. Coxa profunda sign is the only radiographic indicator 
that correlates with an unsatisfactory clinical outcome. A low preoperative HHS ( $<60$ points) may increase the risk of failure.

\section{Declaration of conflicting interests}

The authors declared no conflicts of interest with respect to the authorship and/or publication of this article.

\section{Funding}

The authors received no financial support for the research and/or authorship of this article.

\section{REFERENCES}

1. Beck M, Kalhor M, Leunig M, Ganz R. Hip morphology influences the pattern of damage to the acetabular cartilage: femoroacetabular impingement as a cause of early osteoarthritis of the hip. J Bone Joint Surg Br 2005;87:1012-8.

2. Ganz R, Parvizi J, Beck M, Leunig M, Nötzli H, Siebenrock KA. Femoroacetabular impingement: a cause for osteoarthritis of the hip. Clin Orthop Relat Res 2003;417:112-20.

3. Ganz R, Gill TJ, Gautier E, Ganz K, Krügel N, Berlemann U. Surgical dislocation of the adult hip a technique with full access to the femoral head and acetabulum without the risk of avascular necrosis. J Bone Joint Surg Br 2001;83:1119-24.

4. Koçkara N, Bursali A, Issin A, Gürsu SS, Yildirim T, Sahin V. Is open surgery effective in early-term in patients with femoroacetabular impingement syndrome?. [Article in Turkish] Eklem Hastalik Cerrahisi 2012;23:72-6.

5. Güngör HR, Kiter E, Ök N, Çatak A. Osteochondral mosaicplasty along with osteochondroplasty of the femoral head in femoroacetabular impingement: a case report. Eklem Hastalik Cerrahisi 2015;26:181-4.

6. Leunig M, Beck M, Dora C, Ganz R. Femoroacetabular impingement: Etiology and surgical concept. Oper Tech Orthop 2005;15:247-55.

7. Harris WH. Traumatic arthritis of the hip after dislocation and acetabular fractures: treatment by mold arthroplasty. An end-result study using a new method of result evaluation. J Bone Joint Surg [Am] 1969;51:737-55.

8. Clohisy JC, Carlisle JC, Beaulé PE, Kim YJ,
Trousdale RT, Sierra RJ, et al. A systematic approach to the plain radiographic evaluation of the young adult hip. J Bone Joint Surg [Am] 2008;90:47-66.

9. Tannast M, Siebenrock KA, Anderson SE. Femoroacetabular impingement: radiographic diagnosis--what the radiologist should know. AJR Am J Roentgenol 2007;188:1540-52.

10. Sahin M, Calisir C, Omeroglu H, Inan U, Mutlu F, Kaya T. Evaluation of Labral Pathology and Hip Articular Cartilage in Patients with Femoroacetabular Impingement (FAI): Comparison of Multidetector CT Arthrography and MR Arthrography. Pol J Radiol 2014;79:374-80.

11. Reiman MP, Goode AP, Cook CE, Hölmich P, Thorborg K. Diagnostic accuracy of clinical tests for the diagnosis of hip femoroacetabular impingement/labral tear: a systematic review with meta-analysis. Br J Sports Med 2015;49:811.

12. Laborie LB, Lehmann TG, Engesæter IØ, Eastwood DM, Engesæter LB, Rosendahl K. Prevalence of radiographic findings thought to be associated with femoroacetabular impingement in a population-based cohort of 2081 healthy young adults. Radiology 2011;260:494-502.

13. MacFarlane RJ, Konan S, El-Huseinny M, Haddad FS. A review of outcomes of the surgical management of femoroacetabular impingement. Ann R Coll Surg Engl 2014;96:331-8.

14. Papalia R, Del Buono A, Franceschi F, Marinozzi A, Maffulli N, Denaro V. Femoroacetabular impingement syndrome management: arthroscopy or open surgery? Int Orthop 2012;36:903-14.

15. Nwachukwu BU, Rebolledo BJ, McCormick F, Rosas S, Harris JD, Kelly BT. Arthroscopic Versus Open Treatment of Femoroacetabular Impingement: A Systematic Review of Medium- to Long-Term Outcomes. Am J Sports Med 2016;44:1062-8.

16. Diesel CV, Ribeiro TA, Coussirat C, Scheidt RB, Macedo CA, Galia CR. Coxa profunda in the diagnosis of pincertype femoroacetabular impingement and its prevalence in asymptomatic subjects. Bone Joint J 2015;97:478-83.

17. Nepple JJ, Lehmann CL, Ross JR, Schoenecker PL, Clohisy JC. Coxa profunda is not a useful radiographic parameter for diagnosing pincer-ty pe femoroacetabular impingement. J Bone Joint Surg [Am] 2013;95:417-23. 